\title{
New record of genus Pallisentis Van Cleave, 1928 (Acanthocephalan: Quadrigyridae) in Little Cormorant, Phalacrocorax niger (Aves: Phalacrocoracidae) from Sindh, Pakistan
}

\author{
Muhammad Moosa Abro ${ }^{1 *}$, Ali Murtaza Dharejo ${ }^{2}$, Muhammad Munif \\ Khan $^{2}$ and Nadir Ali Birmani ${ }^{2}$ \\ 1. Government College Hyderabad Postgraduate Center, Hyderabad Sindh-Pakistan \\ 2. Department of Zoology, University of Sindh, Jamshoro-Pakistan \\ *Corresponding author's email: abromusa@gmail.com \\ Citation \\ Muhammad Moosa Abro, Ali Murtaza Dharejo, Muhammad Munif Khan and Nadir Ali Birmani. New record of \\ genus Pallisentis Van Cleave, 1928 (Acanthocephalan: Quadrigyridae) in Little Cormorant, Phalacrocorax niger \\ (Aves: Phalacrocoracidae) from Sindh, Pakistan. Pure and Applied Biology. Vol. 6, Issue 1, pp32-39.
} http://dx.doi.org/10.19045/bspab.2016.50163

\begin{tabular}{llll}
\hline \hline Received: 20/08/2016 & Revised: 09/12/2016 & Accepted: 16/12/2016 & Online First: 21/12/2016 \\
\hline \hline
\end{tabular}

\section{Abstract}

Helminth Parasites of Little Cormorant, Phalacrocorax niger from central District Sanghar of Sindh Pakistan were investigated during December 2014-2015. Little Cormorant, P. niger is fish eating, migratory cum resident bird, harbour diverse parasites and commonly found in water bodies of the study area. Eleven hosts (P. niger) were examined in Parasitological Laboratory of Zoology department, Sindh University Jamshoro. Only one host was harbouring two specimens of acanthocephalan. These were collected from intestine and have proboscis with four circles of spines, eleven circle of collar spine with 14 spines in each circle, sacculate proboscis receptacle, tubular lemenisci, cylindrical testes and long cement glands. These features correspond to generic features of genus Pallisentis Van Cleave, 1928. However, genus Pallisentis usually collected from freshwater fishes and has not been reported from birds. Therefore, present infection in Little Cormorant might be result of its piscivorous feeding habit. Present paper deals first record of genus Pallisentis Van Cleave, 1928 in Little Cormorant, P. niger from Pakistan.

Keywords: Acanthocephalan; Little Cormorant; Phalacrocorax niger; Pallisentis; Intestine

\section{Introduction}

Pakistan is an important habitat and destination for resident as well as migratory birds. She has diverse geography and variety of ecosystems which attract the large birds' population. The different seasons and favourable climate of this region favour avifauna to live and reproduce. Over 560 species of birds are reported in Pakistan [1]. Sindh province is one of such important 
places for avifauna in Pakistan. District Sanghar is one of important districts of Sindh which hosts more than 136 species of avifauna including non-passerine and passerine. Sanghar also hosts large population of Little Cormorant ( $P$. niger) [1] which was selected for helminthic study. Little Cormorant is aquatic and fish eating bird [2] and usually live in fresh water inlands, lakes, and coastal areas. It is voracious piscivorous consequently badly affecting commercial and recreational fishing. Cormorants have the potential to significantly damage fish stock and affect fish quality. It also produce impacts on aquaculture seriously even some time ruin it [3]. In Sanghar District freshwater lakes, canals, water reservoir are the favourable habitats for the Little Cormorant $P$. niger. These water bodies are used for culturing fishes. Thus, the host under study ( $P$. niger) has reasonable chances to acquire infection from fishes.

Acanthocephalans in avian hosts generally and Little Cormorant ( $P$. niger) especially are not well known in Pakistan. There is dire need of considerable and comprehension study on it. A few scholars have tested their stamina to study Avian Acanthocephalan including Khan and Bilqees, [4], Khan et al. [5, 7, 8], Bilqees and Khan, [9], Bilqees et al. [10], Khan et al. [11], Muti-urRehman et al. [12, 13], Khan, [14] and Birmani et al. [15]. But none of them studied Acanthocephalan of Little Cormorant (P. niger). Purpose of present paper is to report first record of genus pallisentis from Little Cormorant ( $P$. niger). However, four species of genus pallisentis including $P$. kalriai Khan et Bilqees [16], $P$. magnum Saeed et Bilqees, [17], P. munifi Naqvi et al. [18] and $P$. sindhensis Khan et Bilqees, [19] already reported from different species of fishes. The present specimen is first record of genus Pallisentis from avian host, particularly in Little Cormorant from
Pakistan (Table 1). Moreover, Little Cormorant ( $P$. niger) studied by Akram, [20], Dharejo et al. [21] and Abro et al. [2228]. They recorded Contracaecun bubakii, Nigerina, Clinostomum complanatum, Clinostomum awadhi, Macrobilharzia macrobilharzia, Paryphostomum sanghari, Paryphostomum radiatum, Pseudapatemon and Euclinostomum heterostomum in Pakistan.

\section{Materials and methods}

Little Cormorant, $P$. niger $(n=11)$ were captured alive from different water bodies of Sanghar District of Sindh Pakistan. These were transported to Parasitological Laboratory of Zoology department, Sindh University Jamshoro. The hosts were anesthetized and dissected ethically. The alimentary canal from esophagus to cloaca was removed from each host and scraped carefully for the presence of helminth parasites. The contents of sample were examined under binocular stereomicroscope. Two acanthocephalan specimens were recovered from intestine of one host. They were washed in in normal saline and passed in graded alcohol series and fixed in $70 \%$ alcohol. The thick specimens were pressed in between plain slides and tied with thread and kept for overnight in $70 \%$ alcohol. After pressing, the threads were untied on next day. Fixed acanthocephalans were stained with Borax Carmine for 5 to 20 minutes depending upon the size and thickness of the specimen. After that, they were washed twice in $70 \%$ alcohol to remove excess stain and transferred into $90 \%$ and $100 \%$ alcohol subsequently for 5 to 20 minutes. Later on, specimens were transferred into clove oil for shining. Then specimens were cleared in xylene about five minutes. Finally specimens were mounted in Canada Balasm for detailed study. The mounted specimens were transferred in oven at $50{ }^{\circ} \mathrm{C}$ to $55{ }^{\circ} \mathrm{C}$ for overnight. 


\section{Results}

Eleven hosts were dissected and only one was infected with two acanthocephalan parasites $(9.1 \%)$. The description is given below.

\section{Description}

Body of the acanthocephalan is cylindrical measuring 3.45 in length, 0.32 in width and maximum wide at collar region (Figure A and B). Proboscis is prominent, well developed, globular, invaginated inside the trunk (Figure C and D) and measuring 0.22 long and 0.145 wide, equipped with 4 circles of fine recurred hooks, $8-10$ hooks in each circle, hooks are same in shape but vary in size. Hooks of first circles are strong, large and consisted of well developed root and sharp blade, measuring 0.093-0.106 in length. Neck is prominent measuring 0.22 in length and without hooks. Proboscis receptacle is sac or bag like, muscular, measuring 0.50 in length and 0.191 in width. Lemensci tubular, equal in size, larger than proboscis receptacle. Both lemnsci are 0.808 long and 0.058 wide. Body consists of collar and trunk spines. Collar spines are arranged in eleven circles, each circle contains 14 spines. Posterior to collar is unspinned region, which is followed by almost 21 rings of spines remaining part is devoid of spines. Anterior testis is 0.205 long and 0.088 wide. A posterior testis is $0.235 \mathrm{long}$ and 0.088 wide. Seminal vesicle is 0.514 long and 0.058 wide. Cement glands are 2-3, well developed, cylindrical and measuring 0.22 long 0.102 wide. Cement gland and cement reservoir joins bursa. Saefftigen pouch is present and elongated in shape.

\section{Taxonomic status of Palliesntis spp. (Figure A-D)}

\section{Family}

Genus

\section{Host}

No. of specimens recovered No. of hosts found positive Site of infection

Locality

Record
Quadrigyridae

Pallisentis Van Cleave, 1928

Syn. Farzandia Thapar, 1931

Neosentis Van Cleave, 1928

Little Cormorant, Phalacrocorax niger

02

01 out of 11

Intestine

Sanghar, Sindh, Pakistan

New host record 

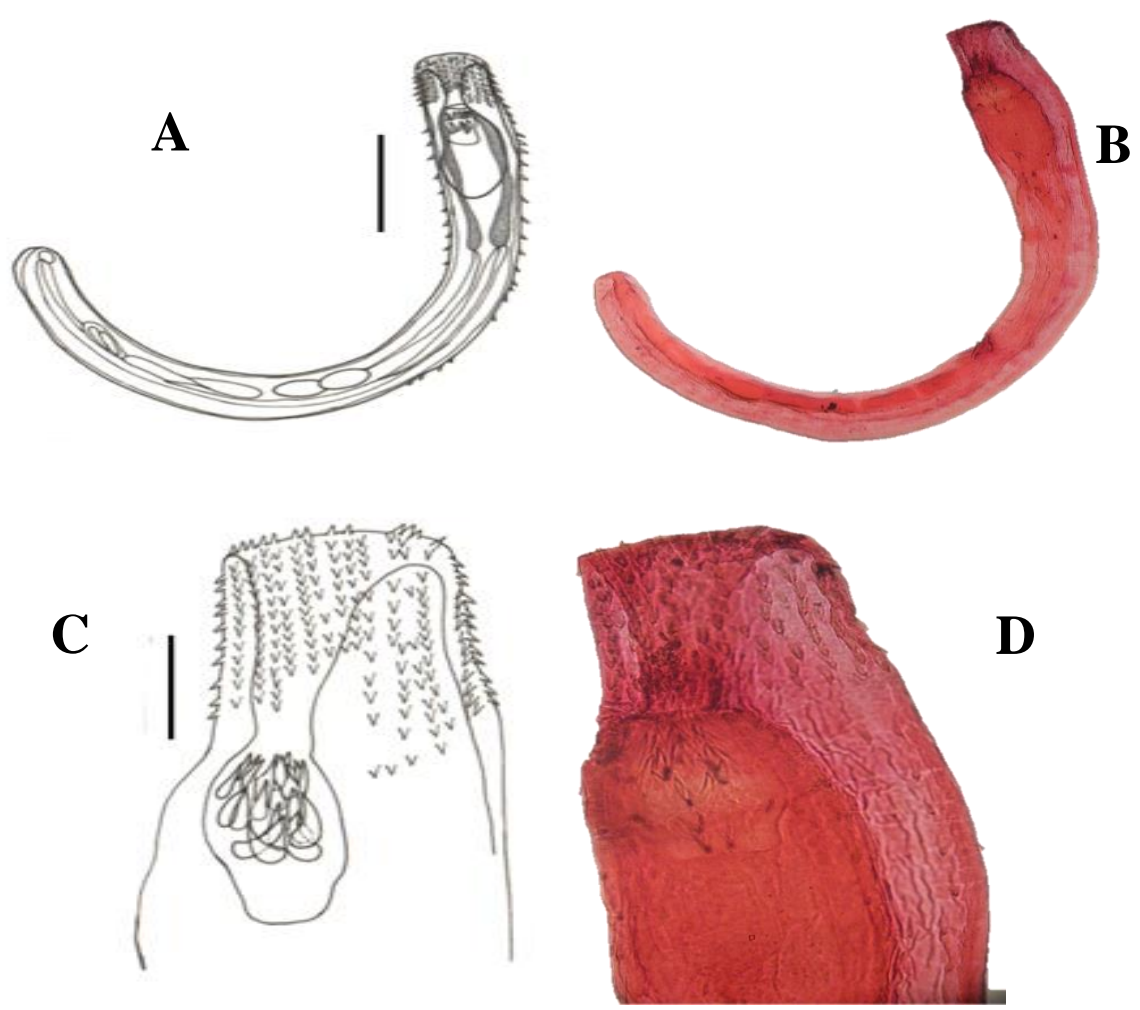

Figure. A and B entire Pallisentis Sp. C and D anterior end of worm. Scale Bar: A. 0.5 mm and C. $0.1 \mathrm{~mm}$

\section{Discussion}

Genus Pallisentis was proposed by Van Cleave, 1928 with Pallisentis umbellatus Van Cleave, 1928 as type species. It is commonly reported from freshwater fishes especially Ophicephalus argus, Siniperca sp;

Cobitis

decemcirrosus and Parasilurus asotus (Table 1) [29]. Many species of genus Pallisentis are reported from various hosts and localities (Table 1), on the basis of Proboscis with four circles of 8-10 spines, eleven circles of collar spines with 14 spines in each circle, sacculate proboscis receptacle, tubular lemenisci, cylindrical testes, long cement gland and saefftigen pouch. Specimens collected during present study resemble generic features of Pallisentis as described in description. Therefore, these are identified as genus Pallisentis. However, its species level identification cannot be confirmed correctly due less number of specimens and recovered specimen have invaginated proboscis, which misled exact counting of circle and number of spines. Moreover, from literature survey it was noted that, this genus of acanthocephalan usually collected from fresh water fishes. Present recovery from Phalacrocorax niger is unusual and may be accidental. Therefore, authors collectively decided to not go for species level identification. Furthermore, Little Cormorant, Phalacrocorax niger host is voracious piscivorous and probably it has acquired infection by eating fishes. Present study has recorded only two male specimens from intestine of single host. These specimens were found along with trematodes and were not embedded in the tissue of intestine. It is seen that acanthocephalan strictly attached with host tissue. Therefore, accidental acquiring of infection may not be ruled out completely. Moreover, genus Pallisentis has wide variation within species and sometime 
procedure of fixing may cause deviation in structure of diagnostic features. Therefore describing present specimen up to species level needed sufficient collection of male as well as female. Therefore, present specimen is identified up to generic level and genus is recorded for the first time from Little Cormorant, $P$. niger in Pakistan (Table 1). Present report establishes a new host record for genus Pallisentis.

Table 1. Name of species of genus pallisentis along with host and locality

\begin{tabular}{|c|c|c|c|c|}
\hline S.No & Name of species & Host & Locality & References \\
\hline 1 & $\begin{array}{l}\text { Pallisentis allahabdii } \\
\text { Agrawal, } 1958\end{array}$ & Ophiocephalus marulius (Pisces) & India & $\begin{array}{l}\text { Bhattacharya, [30] } \\
\text { Agrawal, [31] }\end{array}$ \\
\hline 2 & P. basiri Farooqi, 1958 & Rhynchobdella aculeate (Pisces) & India & $\begin{array}{l}\text { Bhattacharya, [30] } \\
\text { Farooqi, [32] }\end{array}$ \\
\hline 3 & P. buckeyi Tadross, 1966 & Unidentified fish (Pisces) & India & $\begin{array}{l}\text { Bhattacharya, [30] } \\
\text { Tadross, [33] }\end{array}$ \\
\hline 4 & $\begin{array}{l}\text { P. channai Gupta et al., } \\
2015\end{array}$ & Channa punctatus (Pisces) & India & Gupta et al. [34] \\
\hline 5 & P. cleatus Van Cleave, 1928 & Monopterus javanensis (Pisces) & China & Yamaguti, [29] \\
\hline 6 & $\begin{array}{l}\text { P. clupei Gupta and Gupta, } \\
1979\end{array}$ & Clupea longiceps (Pisces) & India & $\begin{array}{l}\text { Bhattacharya, [30] } \\
\text { Gupta [35] }\end{array}$ \\
\hline 7 & P. colisai Sarkar, 1956 & Channa punctatus (Pisces) & India & $\begin{array}{l}\text { Bhattacharya, [30] } \\
\text { Sarkar, [36] }\end{array}$ \\
\hline 8 & $\begin{array}{l}\text { P. fotedari Gupta and } \\
\text { Sinha, } 1991\end{array}$ & Clupea longiceps (Pisces) & India & $\begin{array}{l}\text { Bhattacharya, [30] } \\
\text { Gupta and Sinha, [37] }\end{array}$ \\
\hline 9 & $\begin{array}{l}\text { P. garuai Sahay et al., } \\
1971\end{array}$ & Clupisoma garua (Pisces) & India & $\begin{array}{l}\text { Bhattacharya, [30] } \\
\text { Sahay et al. }[38]\end{array}$ \\
\hline 10 & P. guntei Sahay et al., 1967 & $\begin{array}{l}\text { Lepidocephalicthys guntea } \\
\text { (Pisces) }\end{array}$ & India & $\begin{array}{l}\text { Bhattacharya, [27] } \\
\text { Sahay et al. [39] }\end{array}$ \\
\hline 11 & $\begin{array}{l}\text { P. guptai Gupta and } \\
\text { Fatima, } 1985\end{array}$ & Nandas nandas (Pisces) & India & $\begin{array}{l}\text { Bhattacharya, [30] } \\
\text { Gupta and Fatima,[40] }\end{array}$ \\
\hline 12 & P. jagani Koul et al., 1991 & Channa channa (Pisces) & $\begin{array}{l}\text { Jammu } \\
\text { Kashmir }\end{array}$ & $\begin{array}{l}\text { Bhattacharya, [30] } \\
\text { Koul et al. }[41]\end{array}$ \\
\hline 13 & $\begin{array}{l}\text { P. kalriai Khan et Bilqees, } \\
1985\end{array}$ & Labeo rohita (Pisces) & Pakistan & Khan et Bilqees, [16] \\
\hline 14 & $\begin{array}{l}\text { P. magnum Saeed et } \\
\text { Bilqees, } 1971\end{array}$ & Wallago attu (Pisces) & Pakistan & Saeed et Bilqees, [17] \\
\hline 15 & $\begin{array}{l}\text { P. mehrai Gupta and } \\
\text { Fatima, } 1985\end{array}$ & Caranx kalla (Pisces) & India & $\begin{array}{l}\text { Bhattacharya, [30] } \\
\text { Gupta and Fatima,[40] }\end{array}$ \\
\hline 16 & P. munifi Naqvi et al., 2015 & Cirrhinus mrigala (Pisces) & Pakistan & Naqvi et al. [18] \\
\hline 17 & $\begin{array}{l}\text { P. nagpurensis Bhalerao, } \\
1931\end{array}$ & Ophiocephalus striatus (Pisces) & India & $\begin{array}{l}\text { Bhattacharya, [30] } \\
\text { Bhalerao, [42] }\end{array}$ \\
\hline 18 & P. nandai Sarkar, 1953 & Nandas nandas (Pisces) & India & $\begin{array}{l}\text { Bhattacharya, [30] } \\
\text { Sarkar [43] }\end{array}$ \\
\hline 19 & $\begin{array}{l}\text { P. ophicephali Thapar, } \\
1930\end{array}$ & Channa marulius (Pisces) & India & $\begin{array}{l}\text { Bhattacharya, [30] } \\
\text { Thapar, [44] }\end{array}$ \\
\hline 20 & P. pandei Rai, 1967 & Channa punctatus (Pisces) & India & $\begin{array}{l}\text { Bhattacharya, [30] } \\
\text { Rai, [45] }\end{array}$ \\
\hline 21 & $\begin{array}{l}\text { P. punctati Gupta et al., } \\
2015\end{array}$ & Channa punctatus (Pisces) & India & Gupta et al. [46] \\
\hline 22 & $\begin{array}{l}\text { P. sindhensis Khan et } \\
\text { Bilqees } 1987\end{array}$ & Fishes (Pisces) & Pakistan & Khan et Bilqees, [19] \\
\hline 23 & $\begin{array}{l}\text { P.umbellatus Van Cleave, } \\
1928\end{array}$ & Ophiocephalus argus (Pisces) & China & Yamaguti, [29] \\
\hline 24 & P. vinodai & Channa punctatus (Pisces) & India & Gupta et al. [34] \\
\hline 25 & Pallisentis sp. & Phalacrocorax niger (Aves) & Pakistan & Present study \\
\hline
\end{tabular}




\section{Conclusion}

Genus Pallisentis recorded for the first time from avian host Little Cormorant, Phalacrocorax niger. Present report will help to understand diversity of acanthocephalan in avian fauna of Pakistan.

\section{Authors' contributions}

Conceived and designed the experiments: MM Abro \& AM Dharejo, Performed the experiments: MM Abro \& NA Birmani, Analyzed the data: MM Khan, Wrote the paper: MM Abro \& NA Birmani.

\section{References}

1. Rais M, Khan ZM, Abbas D, Akber G, Nawaz R \& Saeed-ul-Islam (2011). A quantitative study on wildlife of Chotiari reservoir Sanghar, Sindh, Pakistan. Pakistan J Zool 42(2): 237-247.

2. Sarker NJ \& Naher H (2002). Experimental studies on food habits of the Little Cormorant, Phalacrocorax niger (Vieillot). Bangladesh J Zool 302: 173182.

3. Chozyhiyattel Z (2009). Behavior and adaptation of Little Cormorant Phalacrocorax niger and Darter Anhinga melanogaster. Ph. D. Thesis. Post Grad \& Res Dept Zool, St. Joseph's college, Devagiri, Calicut. Kerala India.

4. Khan A \& Bilqees FM (1998). On a new Acanthocephala parasite from Common House Crow in Sindh, Pakistan. Pakistan J Zool 30(1): 35-37.

5. Khan A, Bilqees FM \& Ghazi RR (2001). Acanthocephalan parasite Centrorhynchus nickolin sp.n. from Eurasian Roller (Coracias garrulous Lin.). Proceedings of Parasitol 32: 3339.

6. Khan A, Ghazi RR \& Bilqees FM (2002). Two new species of Acanthocephalan parasites of House Crow (Corvus splendens Vieillot). Pakistan J Zool 34 (2): 139-146.

7. Khan A, Bilqees FM \& Muti-Ur-Rehman (2004). Two new species of genus Mediorhynchus Van Cleave, 1916 from birds of Karachi, Pakistan. Pakistan J Zool 36: 139-142.

8. Khan A, Bilqees FM \& Muti-Ur-Rehman (2005). Lueheia karachiensis new species (Acanthocephala: Plagiorhynchidae) from a bird in Karachi, Pakistan. Pakistan J Zool 37: 113-115.

9. Bilqees FM \& Khan A (2005). Two new helminth parasites from Pakistan with redescription of the acanthocephalan, Centrorhyncus fasciatum (Westrumb, 1821). Pakistan J Zool 37: 257-263.

10. Bilqees FM, Khan A, Khatoon N \& Khatoon S (2007). Acanthocephala from eagle of Karachi with description of two new species. Proceedings of Parasitol 43: 15-26.

11. Khan A, Dharejo AM, Birmani NA, Bilqees FM \& Khan MM (2008). Description of a new Acanthocephalan Polymorphus fatimaae n.sp. (Acanthocephala: Polymorphidae) from Crow (Corvus splendens Vieillot). International J Biol Biotech 5(1-2): 3336.

12. Muti-ur-Rehman, Khan A, Bilqees FM \& Khatoon N (2008). Description of Polymorphus mohiuddini n.sp. (Acanthocephala: Polymorphidae) from the Owl (Strix leptogrammica Temminck). Proceedings of Parasitol 46: 101-107.

13. Muti-ur-Rehman, Khan A, Khatoon N \& Bilqees FM (2010). A new acanthocephalan species Porrorchis jonesae from a bird, Acridotheres tristris (Lin.) from Karachi, Sindh. Pakistan J Zool 42 (2): 157-159.

14. Khan A, Muti-ur-Rehman, Bilqees FM \& Khatoon N (2010). Centrorhynchus amini sp. n. (Acanthocephala: Centrorhynchidae) from a bird with a key to species from Pakistan. Proceedings of Parasitol 49: 77- 88.

15. Birmani NA, Dharejo AM \& Khan MM (2011). A new species of Polymorphus Lühe, 1911 (Acanthocephala: Polymorphidae) in Black Coot, Fulica 
atra (Aves: Rallidae), Pakistan. Zootaxa 29: 64-68.

16. Khan A \& Bilqees FM (1985). Pallisentis kalriai new species (Acanthocephalan: Quadrigyridae) from the fish Labeo rohita of Kalri Lake, Sindh, Pakistn. The Philip J Sci 114(12): 101-111.

17. Saeed R \& Bilqees FM (1971). Pallisentis magnum, new species (Acanthocephalan: Quadrigyridae) from the fish Wallago attu of Kalri Lake Pakistan. Pakistan J Zool 3:221-223.

18. Naqvi SM, Gazi RR, Khan A \& Noor-un Nissa (2015). Pallisentis munifi sp.n (Acanthocephalan: Quadrigyridae) in a freshwater fish mrigal carp (Cirrhinus mrigala Hamilto, 1822) of Kalri lake Sindh Pakistan. International $J$ Bio Biotech 12(2): 243-245.

19. Khan A \& Bilqees FM (1987). Two new Acanthocephlan species from freshwater fishes of Kalri lake. Pakistan J Zool 19: 263-271.

20. Akram M (1996). Contracaecum bubakii new species (Nematoda: Anisakidae) from the Cormorant in Pakistan. Pakistan J Zool 28: 131-132.

21. Dharejo AM, Birmani NA \& Khan MM (2010). First record of the genus Nigerina Baugh, 1958 (Trematoda: Opisthorchidae) from Pakistan in avian host little cormorant, Phalacrocorax niger. Proceedings of Parasitol 50: 147151.

22. Abro MM, Dharejo AM, Khan MM \& Birmani NA (2016). First record of Clinostomum complanatum (Trematodes: Clinostomatidae) in Pakistan from Phalacrocorax niger (Aves: Phalacrocoracidae). Biological For An Int J 8(1): 479-483.

23. Abro MM, Dharejo AM, Khan MM \& Birmani NA (2016). A new species of genus Paryphostomum Dietz, 1909 (Trematoda: Echinostomatidae) in Phalacrocorax niger of Pakistan. Journal of Entomol Zool St 4(3): 246249. http://www.entomoljournal.com/
archives/2016/vol4issue3/PartD/4-375.pdf.

24. Abro MM, Dharejo AM, Khan MM \& Birmani NA (2016). A New record of Genus Macrobilharzia Travassos, 1922 (Trematoda:

Schistosomatoidea) in Phalacrocorax niger from Sindh, Pakistan. Journal of Entomol Zool St 4(4): 654-656.

25. Abro MM, Dharejo AM, Khan MM \& Birmani NA (2016). Euclinostomum heterostomum (Rud 1809) Travassos, 1928 (Trematodes: Clinostomidae: Euclinostominae): a new record in avian host Little cormorant (Aves: Phalacrocoracidae) of Pakistan. Journal of Adv Biol Biotech 8(1): 1-5 2016 Article no.JABB.27782.

26. Abro MM, Dharejo AM, Khan MM \& Birmani NA (2016). New host and locality record of Paryphostomum radiatum (Dujardin, 1845) (Trematodes: Echinostomatidae) from Pakistan. Journal of Bio Nat 6(2): 104-108.

27. Abro MM, Dharejo AM, Khan MM \& Birmani NA (2016). New record of genus Pseudapatemon (Trematoda: Strigeidae) in avian host from Pakistan. Journal of Bio Env Sci 9 (3): 125-129.

28. Abro MM, Dharejo AM, Khan MM \& Birmani NA (2016). Description of a new species Clinostomum awadhi n.sp. (Trematoda: Clinostomidae) in Phalacorcorax niger (Aves: Phalacrocoracidae) of Sanghar, Sindh, Pakistan. Journal of NBR 5(3): 122128.

29. Yamaguti S (1963). Systema Helminthum. Vol. X. Acanthocephala. International Publishers, Tokyo.

30. Bhattacharya SB (2007) Handbook on Indian Acanthocephala. Kolkata. Zoological Surv India 255

31. Agarwal SC (1958). A new species of genus Pallisentis (Acanthocephala). Current Sci 27(3): 107. 
32. Farooqi HU (1958). A new species of the genus Pallisentis from a freshwater eel. $Z$ Parasitk 18: 457- 464.

33. Tadross G (1966). On three new acanthocephala of the genera Pallisentis Van

Cleave, Saccosentis gen. nov and Acanthocephalus Koelreuther, from fish. Journal of Helminthol 40(1-2): 155- 180 .

34. Gupta R, Maurya R \& Saxena AM (2015). Two New Species of the Genus Pallisentis Van Cleave, 1928 (Acanthocephala: Quadrigyridae) from Intestine of Channa punctatus (Bloch, 1793) from the River Gomti at Lucknow, India. Iran J Parasitol 10(1): 116-121.

35. Gupta SP \& Gupta RC (1979). On six new Acanthocephalan parasites from marine fishes of Arabian sea at Quilon, Kerala. Indian J Helminthol 31(2): 135156.

36. Sarkar HL (1956). On a new acanthocephalan Pallisentis colisai from the fish Colisa fasciatus with a note on Acanthogyrus acanthogyrus Thapar, from the fish Labeo rohita. Records Indian Mus 52 (2): 349- 362.

37. Gupta V \& Sinha G (1991). On a new Acanthocephalan parasite Pallisentis fotedari sp. nov. from the intestine of a marine fish Clupea longiceps Gunther, from Puri Coast. Indian $J$ Helminthol 43(1): 19-26.

38. Sahay U, Sinha A \& Ghosh AK (1971). On Devendrosentis garuai gen. et. sp. nov. (Neoechinorhynchidae Southwell et Macfie, 1925, Quadrigyridae Van Cleave, 1920), Acanthocephala from a fresh water Indian fish, Clupisoma garuai (Ham). Annales Parasitol Hum Comp 46: 69-80.
39. Sahay U, Nath A \& Sinha A (1967). On an Acanthocephalan from a hill stream fish Lepidocephalicthys guntea (Hamilton). Zoologischer Anz. 178(5): $348-353$.

40. Gupta V \& Fatma S (1985). On some Acanthocephalan parasites (Family Quadrigyridae Van Cleave, 1920) from fishes of Uttar Pradesh and Tamilnadu. Indian J Helminthol 37(2): 149-180.

41. Koul PL, Raina MK, Bambroo P \& Koul U (991). Pallisentis jagani sp. nov. from Channa channa in Jammu. Indian J Helminthol 43(2): 124-128.

42. Bhalerao GD (1931). On a new species of acanthocephalan from Ophiocephalus striatus. Annals Mag Nat Hist Ser 10(10): 569-573.

43. Sarkar HL (1953). On a new acanthocephalan, Pallisentis nandai from the fish Nandus nandus with notes on the other species of the genus. Proceedings Zool Soc Bengal 6(2): 139-147.

44. Thapar GS (1930). On Farzandia, a new genus of Acanthocephalid worms, from the intestine of Ophiocephalus marulius. Annales Mag Nat Hist Ser 10 (9): 7681.

45. Rai P (1967). On four acanthocephalan genera parasitic in freshwater fishes with description of three new species. Indian J Helminthol 19(1): 27- 44.

46. Gupta N, Gupta DK \& Singhal P (2015). Description of Pallisentis (Brevitritospinus) punctati $\mathrm{n}$. sp. (Acanthocephala: Quadrigyridae) from Channa punctatus in Bareilly, Uttar Pradesh, India. Iran J Parasitol 10(4): 605-616. 